\title{
Metaphysics Relevancy in Contemporary Design
}

\author{
Masran Saruwono a, Nor Aniswati Awang Lah a,b \\ a Faculty of Architecture, Planning and Surveying, Universiti Teknologi MARA (UiTM), \\ 40150 Shah Alam, Selangor, Malaysia \\ ${ }^{b}$ MARA Arts and Design Excellence Centre (MADEC), Kolej Kemahiran Tinggi MARA, \\ 71400 Rembau, N. Sembilan, Malaysia \\ aniswati.lah@mara.gov.my
}

\begin{abstract}
This paper presents the findings of a study on metaphysical approaches to building design. Three major Asian cultures are reviewed. There are similarities found in principles towards achieving the occupants' well-being. Functionality became priority and rituals are performed at ensuring the wellbeing and prosperity of future occupants. Whereas, the Chinese-Buddhist practice which is known as Feng Shui, the Indian-Hindu tradition is based on Vastu-Vidya. The Malay-Islam is extractions from religious teachings written in a manuscript called 'The Tajul Muluk'. The paper concludes that metaphysical approaches could still play its roles in the building design today.
\end{abstract}

Keywords: Metaphysics; functional; environology

eISSN: 2398-4279 @ 2016. The Authors. Published for AMER ABRA by e-International Publishing House, Ltd., UK.. This is an open access article under the CC BY-NC-ND license (http://creativecommons.org/licenses/by-ncnd/4.0/). Peer-review under responsibility of AMER (Association of Malaysian Environment-Behaviour Researchers), ABRA (Association of Behavioural Researchers on Asians) and cE-Bs (Centre for EnvironmentBehaviour Studies), Faculty of Architecture, Planning \& Surveying, Universiti Teknologi MARA, Malaysia.

https://doi.org/10.21834/ajqol.v1i3.21 


\subsection{Introduction}

Contemporary building designs have been criticized for having little or no reference to the natural and spiritual dimensions. To a certain extent, this had probably contributed to failures of buildings to perform functionally as intended. Good design can be described as a product that fits its purpose. If it works, then it automatically looks good, functionally performing and sustaining. We have some information about traditional approaches based on old practices that take care of every aspect, but have not been taken seriously. There are many cases where certain functional failures of buildings are just unexplainable despite having through a rigorous design process. Thus, it would be beneficial to rediscover the ancient systems, which may complement the modern approach and considerations in building design.

\subsection{Literature Review}

The term "functionality" is roughly defined as the quality criterion of a building that makes it sustainable and serving the needs of people. It is based on the principle that the ultimate purpose of design where "users' well-being" shall take precedence over other priorities to bring together a sense of dignity and pride within the design environment (Caan, 2011). Caan insists that the core purpose of design is to create a comfort zone in satisfying human five senses, health, and harmonious feelings; thus, encouraging towards a sense of inspiration and motivation. Such philosophy had already been practiced by people of the Malay ancient kingdom (Al-Ahmadi, 2006; Gibbs, 1987) and peoples in other Asian countries like China and India. These practices had established systems that were used as informal guidelines in planning and design for buildings they built or settlements they planned. It is originated from spiritual and religious belief system that embodies what formally known as "metaphysics."

\subsection{Definition of metaphysics}

Metaphysics is a branch of philosophy that consists an abstract theory that beyond the reality (Oxford University Press, 2014). It relates to the unseen flow of "energy forces" that can be felt through experiencing. "Energy" was identified as the ability to be active regarding the physical or mental strength. It allows people to behave which relates to the natural enthusiasm and effort; usable power that comes from heat, electricity, etc. (Merriam Webster, 2014). The metaphysical approach revolves around the Universe and the Earth. It interconnects to each other by an "electromagnetic field" and other forces, such as gravity, uptake of earth forces, cosmic forces, etc. The same applies for buildings designed by humans, which aim at achieving sustainability. 


\subsection{Methodology}

A comparative study was carried out to obtain a clear understanding of the philosophy behind the ancient belief systems of Chinese, Indian and Malay-Islam. The factors, the components and the elements of traditional metaphysics and how each influences the functionality of building design and, ultimately the occupants' well-being. The analysis focused on the similarities and differences between the three cultures. The outcome would make us decide whether these spiritually based ancient approaches would still relevant in present context.

\subsection{The Chinese environology}

The Chinese have a tradition and belief system, originated some 1,000 years ago, known as "Feng Shui (Lip, 1997). The word "Feng" means the wind and "Shui" means water (Huang, 2012), which is now commonly known as "environology." It is the art of placement concerning to the physical landform, climatic conditions, geographical location, and so on. The theory of five elements is a concept on how humans benefitted from the balanced interaction with nature. The five elements and producing cycle in chronological manners are water, wood, fire, earth, and metal. The ancient Chinese believed that the universe consisted of the union of "yin" and "yang." There are four basic Feng Shui methods in Environology practices: identification, selection, matching and energizing the internal or even external environments. It involves a very sophisticated system with a combination of numerical binary number sectors with a magnetic compass that can only be done by a professional Environology Master.

Environology practices attempt to plan for the quality of energy that may influence people's happiness and prosperity. To enjoy success, people need a "yang" or "vibrant chi" (positive energy), which supports the life of the human body, homes or buildings. When a building's life force is lively and dominated by vibrant positive energy, its occupants' moods tend to be active and happy. The "yin" chi (negative energy) can be extremely harmful. It may cause a daily build-up of stale, tired energy resulting by dead insects, peel paint, damp newspapers, and magazines, die plant, and junks built up over time. The stillness of that stuff causes the "yin chi" to build up. The main reason of tired energy is the physical, emotional and spiritual clutter that engulfs a living space. Reverting from bad energy to positive where beneficial chi can be achieved through chi maintenance - energizing and enhancing the living space, mind and body.

\subsection{The Indian vastu-vidya}

The Indian term "Vastu" means to dwell and "Vidya" means science (Pegrum, 2000). Indian culture also believed that there are five natural elements - ether, earth, air, water, and fire which are known as Maha Bhutas (Pegrum, 2000). All the five elements are in the form of human's five senses (hearing, touch, sight, taste and smell). The elements need to be present within a space to make it vibrant and filled with positive energy. According to Indian 
philosophy, if the house is properly laid out according to the five elements, the living occupants will be normal and enjoy good health. As Pegrum noted, the Ancient Sages of India claimed that the cosmic energy was receiving from the northeast (Eashanya) and moves towards the southwest. It is essential to create a "preserving zone", by keeping the southwest corner blocked (no doorways), the positive energy entering from the northeast will be prevented from leaving the space.

\subsection{The Malay-Islamic metaphysical architecture}

The Islamic description of the energy as "zat" and all types of energy belongs to Allah s.w.t. Islam believes that controlling human desire (nafs) can produce a positive energy (soft vibratory frequency - nuriman). The desire can be controlled with proper attitudes, uttering verses, the humility of salat, patience, contributing benefits towards others' life, a group of salat, knowledge understanding, and healthy interaction with nature. According to Mustofa (2011), the humility of "salat" towards Allah s.w.t produces higher positive ion energy. It is probably based on this theory that group "salat" (jamaah) becomes the compulsory rituals of Malay-Islamic people before inhabiting a new building. This practice is compatible with the modern science called "resonance." Resonance happens when the same frequencies of energy that meet each other will automatically transform into an extra-large frequency of energy. Since the wood as an element of nature tends to absorb energy from surroundings, this ritual becomes a part of positive ion energy accumulation towards the center.

\subsection{Discussions}

The chief goal of designing buildings in all cultures is to attain well-being for its occupants. Malay architecture had evolved through the years influenced by their religious beliefs, which started from animism to Hinduism and finally, Islam. Islam believes that human's creation became the most important invention and preferred by Allah. When the energy inside human generated by heart can be corrected, all other God's creations such as water, fire, wind, earth, animals, etc. will move correctly (Abidin, 1984). The heart becomes the most important organ in the body that will directly affect human behavior. A soft vibratory frequency, called 'nuriman' or electromagnetic energy in modern scientific terms, is produced by the heart and can influence the human mind and body (Mustofa, 2011).

\subsection{Assessing the Malay-Islamic architecture}

The element 'tiangseri' in Malay house is so significant as it represents the heart of human creation. Typically, it is located in the living area and has become the most important part and the first element to be raised up in any Malay building construction. The post perhaps functions as a magnetic bar inside the house. The 'base' is a negative charge, and the 'tip' is a positive charge. This magnetic bar forces the flow of the wind and water towards inside and surroundings of the building. It is similar to the concept of 'the right-hand rule'. 


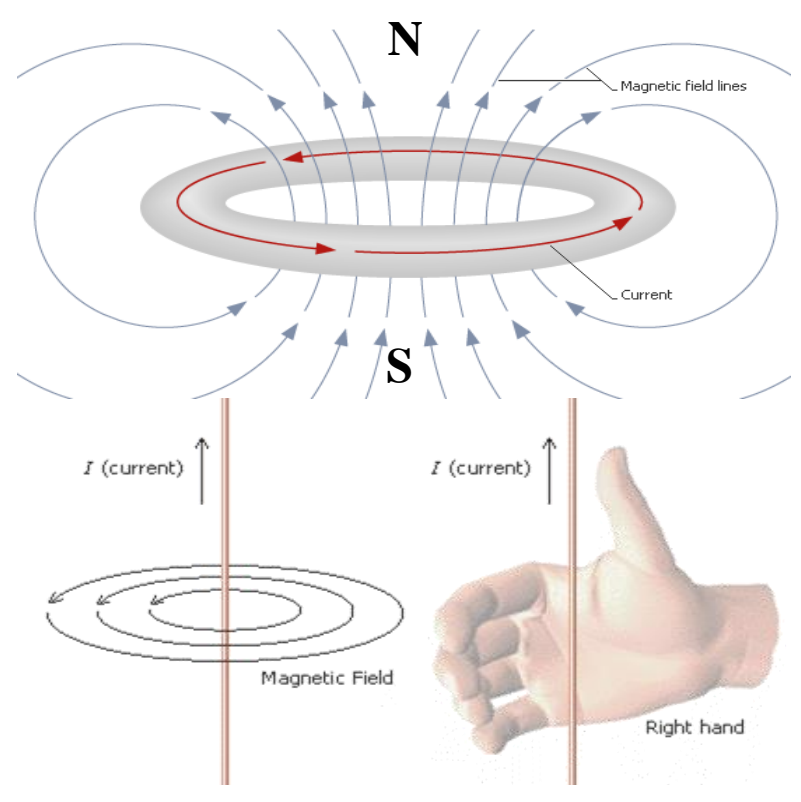

Figure 1: The 'right-hand rule': magnetic field (south-north) around a bar magnet is the close similarity to the electric field (negative-positive) by modern sciences study.

(Source: Electricity, 2009)

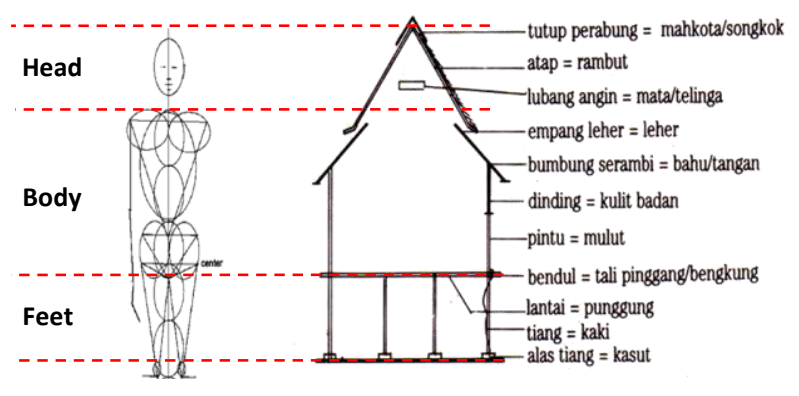

Figure 2: The human body with the Malay house analogy

(Source: Idrus, 1996) 
The Malay traditional house is based on the human's cosmic structure characteristics as shown in Figure 2. The firmness of the form and the aesthetics of the sense of the building were based on how God created human structure and personal characteristics. The house is representing the owners to whom it belongs (Al-Ahmadi, 2006). The external form of the house metaphorically represents the male owner (husband) and his personal characteristics. Meanwhile, the interior space of the house represents the inner body of the female partner (wife) and her personal characteristics. The internal measurement is also based on the measurement of the wife anthropology.

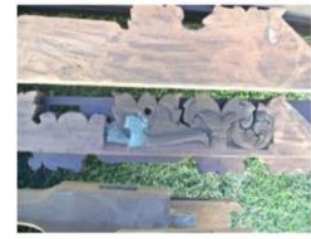

(a)

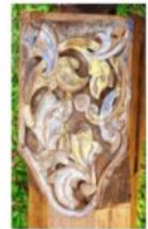

(b)

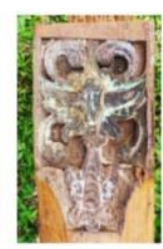

(c)

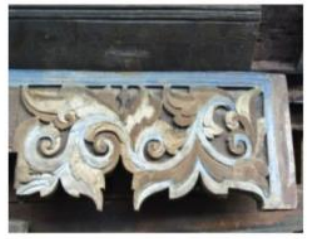

(d)

Figure 3: (a) The carving motif that represented genetic inheritance symbolism; (b), (c) and (d) shows the motivation and belief of personal characteristics in rumahTukangKahar, Negeri Sembilan

Different carving motifs represent genetic inheritance symbolism and individual features of the owner of the 'Tukang Kahar' (Kahar the Craftsman) house in Negeri Sembilan. It becomes one of the most identifiable houses in traditional Malay-Islamic architecture and it still stands after more than 100 years old. (Rasdi, Ali, Ariffin, Mohamad, \& Mursib, 2005). Figure 3(a) shows the motif of carving tool of a craftsman. According to a renowned Malay tukang, the motif is the same with one found in Sumatera. Perhaps their ancestors came from the same origin and inherited a craftsmanship. The 'Tukang Kahar' is a well-known artist who designed and built the Istana Seri Menanti. He is very knowledgeable about Malay-Islamic architecture with a high quality of workmanship through a combination of flora and fauna carving motif. His house became the evidence of his professionalism, for which the Malay 'Tajul Muluk' becomes his primary reference guidance.

The experience of space should satisfy all human five senses, visual, smell, sound, touch, and taste, towards the psychological balance in human behavior. The symbols that appear inside and around the building become a reminder for a motivation of identity, culture, and God. Human's sight and hearing should achieve a balance between the natures' surrounding earthy elements and sound. The nose should smell the nature's fresh odors. The taste should be comfortable with the surrounding temperature, air pressure and humidity in achieving thermal comfort. Lastly, the touch should explore the natural varieties of physical sensation. That is fostering the design for the well-being. That basic design discipline and practices is still felt but less commonly carried out today.

The orientation of the building based on the cosmic structure. Frequently, the direction of the building is determined by four cardinal points (baruh, darat, hilir, hulu). The front 
façade of the building should face the baruh, and the back was considered as darat (Idrus, 1996). The baruh refers to a flat terrain land and should face the sunrise, but it sometimes faces the river or a mountain. The face of the building is determined by natural or built object that dominates the external environment. The adjustment depends on site condition, for which nature's element apparently dominates the surrounding environment.

The coming of the Islam to the Malay Kingdom around the 14th century has changed several principles of the previous practice of Malay architecture system. The Malay-Islamic buildings usually face the 'qibla', just like the Muslims do when they perform 'salat'. Muslims believed that the 'qibla' is the strongest energy accumulation of the believers on earth that was directly connected to the heaven (Mustofa, 2011). That's why the toilets are said to be best built away from the direction of 'qibla'. However, there are exceptions towards this orientation as stated in hadiths; narrated Abu Ayyub al-Ansari: Allah's Apostle said: "If anyone of you goes to an open space for answering the call of nature, he should neither face nor turn his back towards the qibla" (Sahih Bukhari, Vol. 1:106). Meanwhile, according to Idrus, the Malay house should face the 'baruh' and one of the longest building sides should face the 'qibla', even less accurate.

The configuration of the building's form and space which should metaphorically base on the concentric composition of the cosmic structure of a human. The 'tiangseri' as the heart of the house becomes the center. Besides, the auspicious shape and form of the building such as square, triangle, and circle with a proportion hierarchy of space also becomes another character towards the energy accumulation. The analysis study shows interrelationship with the patterning of the sympathetic and the parasympathetic divisions of internal organ systems of the human body. The ordering of spaces should be arranged in front-to-back order with the principles of a superiority of internal organ system and its function. Based on the internal organ system placement, the ordering placement system, it seems to be the mouth at the main entrance at the front. There are also secondary and tertiary entries at the 'selang' area and platform area. The 'pangkalserambi' and 'hujungserambi' function as larynx or air passage. It works as a discussion area, but it sometimes becomes as the sleeping area.

The 'rumahtengah' or 'rumahibu' became the primary structure of the house and became the central area of family activity and sleeping. Therefore, the 'tiangseri' is placed at the heart of the house as already discussed previously. It functions to produce electromagnetic energy forces in space and surrounding the building. Environology studies claimed that space needs a dynamic atomic movement to prevent stagnation and to die. That makes the function of living area metaphorically as cardiovascular and respiratory system part of the human body. It became the main controlling center and energy accumulation. 


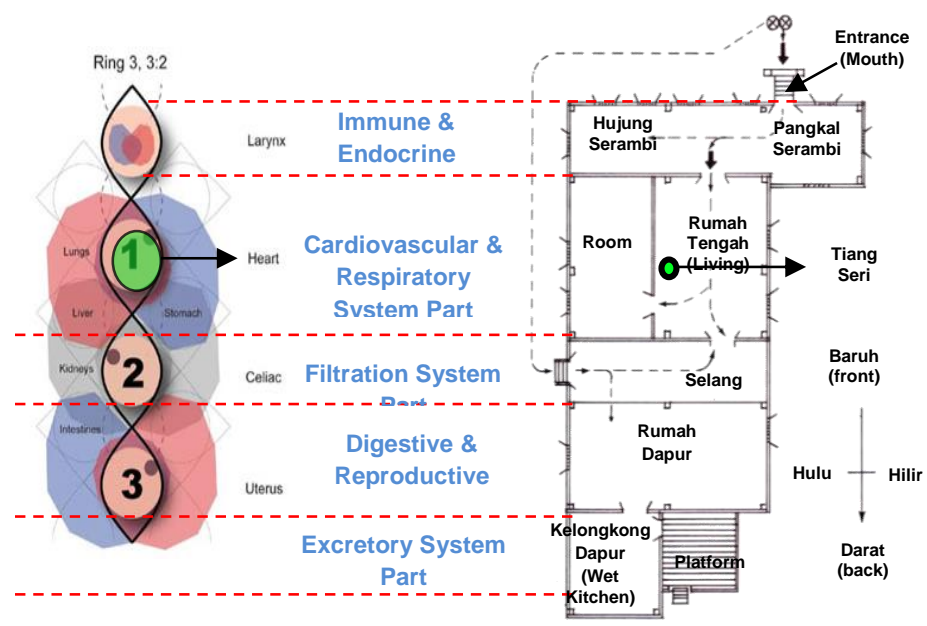

Figure 4: The Internal Human Body Systems with the basic Malay-Islamic Architecture (Source: Idrus, 1996; Merrick, 2014)

The 'selang' divides the space between the 'rumahtengah' and 'rumahdapur'. The 'rumahdapur' is considered to have different energy forces such as heat and rubbish (darkness energy). The heat from the stove and the sunset need to be filtered from transferring into the main living area. The extra heat gain will contribute towards thermal discomfort inside space. It seems the same also with the rubbish; it provides uncomfortable smell and disturbs the occupant behavior psychologically. The placement of both elements is represented as the excretory system part inside the human body. It is placed at the back side of the house.

\subsection{Conclusion}

Metaphysics plays a part in planning and design of buildings, and this principle could complement the modern day approach to design. The concept and theory of metaphysical approach are actually functional that are logical yet practical. The following table summarizes the metaphysical approach principles and its application: 
Table 1: The metaphysical approach principles in related to the traditional functional design characteristics influencing factors

\begin{tabular}{lll}
\hline $\begin{array}{l}\text { Metaphysical } \\
\text { Approach }\end{array}$ & \multicolumn{2}{l}{ Traditional Functional Design Characteristics } \\
\cline { 2 - 3 } & Components & Elements \\
\hline & - Energy Generator & Magnetic bar (heart) \\
& - Orientation & $\begin{array}{l}\text { Determined by four cardinal point } \\
\text { Determined by natural/built } \\
\text { object dominates external } \\
\text { environment }\end{array}$ \\
Human Cosmic Order & - Configuration & Concentric composition
\end{tabular}

Auspicious shape/proportion

\begin{tabular}{lll} 
& - Spatial Hierarchy & $\begin{array}{l}\text { Principles of superiority } \\
\text { (internal human's organs } \\
\text { systems) }\end{array}$ \\
\hline Human Five Senses & - Symbolism & $\begin{array}{l}\text { - Spirits (parents \& ancestor) } \\
\text { - Motivation (religion \& culture) }\end{array}$ \\
& & - Belief (lifestyle \& personality) \\
\hline $\begin{array}{l}\text { Human Cosmic } \\
\text { Structure }\end{array}$ & - Envelope (Skin) & $\begin{array}{l}\text { Auspicious shape/proportion } \\
\text { (external human's anthropology } \\
\text { and anatomy parts) }\end{array}$ \\
\hline
\end{tabular}

The findings from the study show that the Malay Islamic people had practiced human oriented design principles, which based on metaphor. The study provides some evidence that the design of a building shall begin from inside towards outside which may be given less attention by modern philosophy. The analysis has highlighted some rationale behind the practice system It also augurs well with the Vitruvian principles of function (utilitas), firmness (firmitas), and aesthetic (venustas). The highlight of the findings brings us to conclude that metaphysical approach is used to produce energy accumulation inside space and maximizing it by getting the best alignment with the movement of the universe.

\section{Acknowledgement}

This study is carried out to fulfill the requirement for the degree of MSc (Built Environment) at Universiti Teknologi MARA, Shah Alam and is funded by Majlis Amanah Rakyat (MARA). It obtained the support from MARA Research and Innovation Unit under Skim Geran 
Penyelidikan dan Inovasi MARA (SGPIM) 2013 (reference no. MARA/UNI: 1/33/03/24/13). The authors would like to acknowledge the contributions from Professor Master David Koh for his comments and suggestions relating to Environology and also En Alias bin Ali, a renowned wood craftsmen for sharing his knowledge and experience, during the preparation of this paper.

\section{References}

Abidin, M. Z. (1984). Bayan Mufti Zainal Abidin, Ijtima' Yala, Thailand 1984: Nasihat untuk Karkun dalam buat usaha Agama. Perniagaan Darul Khair.

Al-Ahmadi, A. R. (2006). Petua Membina Rumah Melayu: Dari Sudut Etnis Antropologi. Perpustakaan Negara Malaysia.

Caan, S. (2011). Rethinking Design and Interiors: Human Beings in the Built Environment. London: Laurence King Publishing Ltd.

Electricity (2009). Electricity and Magnetism: Electric Effects of Magnetism. Webmaster online, Universidad de Somoso. Retrieved from http://electricity5.blogspot.com/2008/12/ix-electricity-and-magnetism.html visitors

Gibbs, P. (1987). Building a Malay House. Oxford University Press Pte. Ltd., New York.

Huang, E.-Y. (2012). Comparing the Do's \& Taboos in Chinese Feng Shui and Indian Vastu-Shastra architecture traditions. Leiden University. Retrieved from http://hdl.handle.net/1887/18670

Idrus, Y. (1996). Rumah Tradisional Negeri Sembilan: Satu Analisis Senibina Melayu. Penerbit Fajar Bakti Sdn Bhd.

Lip, D. E. (1997). What is Feng Shui. Academy Group Ltd.

Merriam Webster (2014). Merriam-Webster Online Dictionaries: An Encyclopedia Britannica Company. Merriam Webster Inc. Retrieved from http://www.merriam-webster.com/dictionary/business?show=0\&t=1392103204

Merrick, B. R. (2014). Harmonic Evolution Part 2. Token Rock. Retrieved from http://www.tokenrock.com/dna_music/harmonic_evolution2.php

Mustofa, A. (2011). Pusaran Energi Kaabah (edisi kedu.). PTS Millennia Sdn. Bhd.

Oxford University Press (2014). Oxford dictionary (British \& World English). Oxford University Press Web Page. Retrieved from http://www.oxforddictionaries.com/definition/english/energy

Pegrum, J. (2000). The Vastu Vidya Handbook: The Indian Feng Shui (First Ed.). New York: Three Rivers Press.

Rasdi, M. T. M., Ali, K. M., Ariffin, S. A. I. S., Mohamad, R. \& Mursib, G. (2005). The Architectural Heritage of the Malay World: The Tradisional House. Johor, Malaysia: Universiti Teknologi Malaysia, Skudai. 